\title{
PERAN SENYAWA BUAH MENGKUDU (Morinda citrifolia) TERHADAP EKSPRESI CD62L PADA LIMPA MENCIT YANG DIBERI PAPARAN Staphylococcus aureus
}

\author{
Dia Faroka, Sri Rahayu, Muhaimin Rifa'i
}

\author{
Progam Magister Biologi, Fakultas Matematika dan Ilmu Pengetahuan Alam. \\ Universitas Brawijaya, Malang \\ vamazika@yahoo.com
}

\begin{abstract}
Abstrak
S. aureus dapat menyebabkan penyakit toxic shock syndrome, endokartitis, osteomyelitis, pneumonia, sepsis, serta penyakit meningitis. Superantigen bakteri ini dapat mempengaruhi sistem imun melalui sekresi sitokin proinflamasi secara besar-besaran. Resistensi S. aureus terhadap vancomysin, mendorong masyarakat untuk mencari obat alternatif yang berasal dari bahan alam, yaitu tanaman obat tradisional. Salah satu tanaman obat tradisonal yang memiliki potensi sebagai anti mikroba, anti kanker, anti inflamasi dan antioksidan adalah buah mengkudu. Penelitian ini bertujuan untuk mengetahui peran senyawa dari ekstrak air buah mengkudu terhadap ekspresi $C D 4^{+} C D 62 L^{+}$( sel T naif) dan $C D 4^{+} C D 62 L^{-}$( sel T memori ) pada limpa mencit yang diberi paparan $S$. aureus. Pada penelitian ini, mencit dibagi menjadi 2 kelompok yaitu infeksi dan non infeksi. Kedua kelompok tersebut diberi ekstrak air M. citrifolia dengan dosis berturut-turut $25 \mathrm{mg} / \mathrm{kgBB}, 100 \mathrm{mg} / \mathrm{kgBB}$, dan $300 \mathrm{mg} / \mathrm{kgBB}$ selama 20 hari kemudian diinfeksi $S$. aureus sebanyak $1 \times 10^{9}$ sel. Pengamatan jumlah relatif sel $\mathrm{TCD}^{+} \mathrm{CD} 62 \mathrm{~L}^{+}$dan $\mathrm{CD} 4^{+} \mathrm{CD} 62 \mathrm{~L}^{-}$dianalisis menggunakan flow cytometry melalui progam CellQuest dan dilakukan uji statistik ANOVA RAL faktorial dan uji BNJ melalui progam SPSS 16. Hasil penelitian menunjukkan bahwa, pada kelompok non infeksi pemberian dosis $25 \mathrm{mg} / \mathrm{kgBB}$ dan $100 \mathrm{mg} / \mathrm{kgBB}$ tidak berbeda nyata dengan kontrol normal, sedangkan dosis $300 \mathrm{mg} / \mathrm{kgBB}$ terjadi penurunan sel $T$ naif $(P<0.05)$. Sel T naif pada kontol infeksi mengalami penurunan dibandingkan kontrol normal $(P<0.05)$. Sel T memori pada kontrol infeksi mengalami peningkatan dibandingkan kontrol normal $(P<0.05)$ Pada kelompok infeksi dosis $100 \mathrm{mg} / \mathrm{kgBB}$ mampu menurunkan jumlah sel T memori $(P<0.05)$.
\end{abstract}

Kata kunci : Morinda citrifolia, Staphylococcus aureus, $\mathrm{CD}^{+} \mathrm{CD} 62 \mathrm{~L}^{+}, \mathrm{CD} 4^{+} \mathrm{CD} 62 \mathrm{~L}^{-}$.

\begin{abstract}
S. aureus can cause diseases such as toxic shock syndrome, endokartitis, osteomyelitis, pneumonia, sepsis, and meningitis. The bacterial superantigen can affect the immune system through the secretion of proinflammatory cytokines massively. Resistance S. aureus against vancomysin, is encouraged people to seek for alternative drugs derived from natural materials, namely traditional medicinal plants. One of the traditional medicinal plants that have potential as anti-microbial, anti-cancer, anti-inflammatory and antioxidant is noni fruit. The purpose of this research to determine the role of compound extract of noni juice on the expression of $C D 4^{+} C D 62 L^{+}$(naive T cells) and $C D 4^{+} C D 62 L^{-}$(memory T cells) in the spleen of mice that were given exposure to $S$. aureus. In this research, mice were divided into 2 groups: infectious and non-infectious. Both groups were given water extract M. citrifolia with successive doses of $25 \mathrm{mg} / \mathrm{kgBW}, 100 \mathrm{mg} / \mathrm{kgBW}$, and $300 \mathrm{mg} / \mathrm{kgBW}$ for 20 days and then infected with $S$. aureus as many as $1 \times 10^{9}$ cells. Observations relative number $T C D 4^{+} C D 62 L^{+}$cells and $C D 4^{+} C D 62 L^{-}$analyzed using flow cytometry and CellQuest program, and statistical test CRD factorial ANOVA and HSD test through SPSS 16 program. The results showed that, in the group of non-infectious dose $25 \mathrm{mg} / \mathrm{kgBW}$ and $100 \mathrm{mg} / \mathrm{kgBW}$ was not significantly different from normal controls, whereas doses of 300 $m g / k g B W$ decreased naive $T$ cells $(P<0.05)$. Naive $T$ cells in the control infection decreased compared to normal controls $(P<0.05)$. Memory $T$ cells on infection control increased compared to normal controls $(P<0.05)$ On group infection dose of 100 $\mathrm{mg} / \mathrm{kgBW}$ can reduce the number of memory $T$ cells $(P<0.05)$
\end{abstract}

Key words : Morinda citrifolia, Staphylococcus aureus, $C D 4^{+} C D 62 L^{+}, C D 4^{+} C D 62 L^{-}$. 


\section{Pengantar}

S. aureus merupakan bakteri gram positif, bersifat patogen yang bertempat didaerah kulit, saluran pencernaan dan hidung (Lindberg et al., 2004). Bakteri ini juga menyebabkan terjadinya penyakit pneumonia sebesar 2\% dan 10\% nosokomial pneumonia, sedangkan untuk tingkat kematian nosokomial pneumonia mencapai 30\%-80\% (Kaye et al., 1990). S. aureus juga menyebabkan berbagai macam penyakit seperti selulitis, keracunan makanan, toxic shock syndrome, endokartitis, osteomyelitis, sepsis (Lowy, 1998)

Faktor virulen $S$. aureus berupa leukocidin yang masuk kedalam jaringan dapat mematikan sel-sel darah putih (Jawetz et al., 1996). Sedangkan Superantigen S. aureus merupakan antigen yang bersifat mitogen terhadap kerja sel $\mathrm{T}$ melalui ikatan yang spesifik pada bagian $\mathrm{V} \beta$ dari $\mathrm{T}$ cell reseptor (TCR) (Llewelyn, 2002). Ikatan tersebut menyebabkan terjadinya sekresi sitokin proinflamasi $\mathrm{T}$ helper-1 (Th1) secara besarbesaran seperti, Tumor necrosis factor (TNF)$\alpha$, Interleukin-6 (IL-6) dan Interferon- $\gamma$ (IFN- $\gamma$ ). Ketidakseimbangan aktivitas sitokin proinflamasi bertanggung jawab terhadap fisiopatologi dari (STSS) (McCormick et al., 2001; Steven, 1997).

Meningkatnya resistensi $S$. aureus terhadap antibiotic seperti penicillin, methisilin, quinolone dan vancomysin, mendorong masyarakat untuk mencari tanaman obat. Tanaman obat memiliki penting terhadap perkembangan obat terbaru, karena lebih efektif, efek sampingnya lebih kecil, dan harga lebih murah dibandingkan obat sintetik (Raj et al., 2011). Salah satu tanaman obat yang dapat digunakan untuk menjaga kesehatan adalah buah mengkudu. Buah mengkudu memiliki potensi sebagai anti mikroba, anti kanker, anti inflamasi dan antioksidan (Wang et al., 2002). Senyawa alkaloid, flavonoid, saponin, dan steroid pada buah mengkudu dengan tingkat kematangan yang berbeda, dapat beperan sebagai anti bakteri (Ramesh et al., 2012). Scopoletin buah mengkudu juga berfungsi sebagai antibakteri (Duncan et al., 1998). Buah mengkudu dapat meningkatkan imunitas sel dan meningkatkan aktivitas makrofag untuk melawan pertumbuhan tumor (Hirazumi and Furusawa, 1999) Sedangkan juice dari buah mengkudu dapat bersifat sebagai anti inflamasi (Su et al., 2001). Berdasarkan latar belakang tersebut, penelitian ini bertujuan untuk mengetahui peran senyawa buah mengkudu terhadap jumlah relatif dari sel $\mathrm{TCD} 4^{+} \mathrm{CD} 62 \mathrm{~L}^{+}$ (sel $\mathrm{T}$ naif) dan sel $\mathrm{TCD}^{+} \mathrm{CD}^{-} \mathrm{L}^{-}$(sel $\mathrm{T}$ memori) pada limpa mencit yang diinfeksi $\mathrm{S}$. aureus.

\section{Bahan dan Cara Kerja}

Penelitian ini menggunakan Rancangan Acak Lengkap (RAL) Faktorial. Kriteria mencit yaitu, strain DDY, betina, berumur 6 minggu, sebanyak 32 ekor. Hewan coba mencit telah mendapatkan sertifikat kelaikan etik no.112KEP-UB. Mencit diaklimasi selama 1 minggu kemudian diberi perlakuan. Terdapat 2 kelompok, yaitu kelompok infeksi dan kelompok non infeksi. Kedua kelompok tersebut diberi perlakuan ekstrak air buah mengkudu selama 20 hari, kemudian diinfeksi S. aureus pada kelompok infeksi. Pada masingmasing kelompok terdapat 4 perlakuan, dengan 3 ulangan. Kontrol normal kelompok noninfeksi diberi aquades tanpa diinfeksi $S$. aureus, sedangkan kontrol positif kelompok infeksi diberi aquades dan diinfeksi dengan S. aureus.

\section{Pembuatan Ekstrak air buah Mengkudu.}

Tumbuhan mengkudu berumur 2 tahun. daging buah di oven pada suhu $50^{\circ} \mathrm{C}$, selama 5 hari, di blender menjadi serbuk halus,diayak sehingga diperoleh simplisia. 5 gram simplicia dilarutkan dengan $50 \mathrm{ml}$ aquades, dipanaskan hingga mencapai suhu $80^{\circ} \mathrm{C}$, kemudian dipertahankan selama 15 menit (Arifiandari dan Condro, 2007). Dilakukan penyaringan dengan kertas saring, hasil penyaringan merupakan crude ekstrak yang diberikan berdasarkan dosis yang ditentukan. Dosis ekstrak buah mengkudu yang aman untuk manusia 500-1000 mg per hari (Murray, 2000) dan dikonversikan pada mencit dengan cara mengalikan 0.0026 (berat badan mencit $20 \mathrm{mg}$ ). Dosis yang digunakan, $25 \mathrm{mg} / \mathrm{kgBB}, 100 \mathrm{mg} / \mathrm{kgBB}, 300 \mathrm{mg} / \mathrm{kgBB}$. Dosis yang diberikan kepada mencit dihitung terlebih dahulu sesuai dengan berat badan mencit. Dosis diberikan sekali setiap hari, dicekokan secara oral menggunakan sonde lambung selama 20 hari.

\section{Infeksi S.aureus.}

Menginokulasikan $4 \mathrm{ml}$ stok kultur bakteri $S$. aureus didalam media nutrient Broth (NB) sampai $40 \mathrm{ml}$ kemudian di shaker. Pada jam ke-8 (fase log bakteri), diambil $1 \mathrm{ml}$ kultur dimasukkan kedalam ependof dan disentrifuse dengan kecepatan 10.000 rpm selama 10 menit 
dengan suhu $25^{\circ} \mathrm{C}$. Hasil dari sentrifuse, supernatan dibuang, pellet ditambahkan $100 \mathrm{ul}$ PBS dan diinfeksikan kedalam mencit. Jumlah bakteri $S$. aureus yang diinfeksikan $1 \times 10^{9}$ sel. Infeksi dilakukan pada hari ke-21 setelah pemberian ekstrak air buah mengkudu. Infeksi dilakukan secara Intraperitoneal menggunakan syringe dengan ukuran $211 / 2 \mathrm{G}$. Pembedahan mencit dilakukan setelah 5 hari infeksi. Proses imunitas adaptif pada umumnya bekerja 4-7 hari setelah terjadinya infeksi (Rifa'i, 2011).

\section{Isolasi sel dan analisis flow cytometry.} Jumlah relatif $\mathrm{CD}^{+} \mathrm{CD}^{2} \mathrm{~L}^{+}$(sel $\mathrm{T}$ naif) dan $\mathrm{CD}^{+} \mathrm{CD}^{2} \mathrm{~L}^{-}$(sel $\mathrm{T}$ memori) diperoleh dari isolasi sel limpa. Untuk memperoleh sel dari limpa, yaitu organ dipencet dengan pangkal spuit kemudian difilter menggunakan wire. Sel-sel limfosit dari limpa dilarutkan dalam PBS sampai $6 \mathrm{ml}$, kemudian disentrifus dengan kecepatan $2500 \mathrm{rpm}$ pada suhu $4^{\circ} \mathrm{C}$ selama 5 menit. Supernatan dibuang dan pellet diresuspensi dengan PBS $1 \mathrm{ml}$, dipipeting untuk mendapatkan homogenat. Kemudian diambil $100 \mu \mathrm{l}$ homogenat, dimasukkan ke dalam tabung ependof yang sudah berisi $500 \mu \mathrm{l}$ PBS. Setelah itu dilakukan sentrifuse dengan kecepatan $2500 \mathrm{rpm}$, suhu $4^{\circ} \mathrm{C}$ selama 5 menit. Pelet yang diperoleh ditambahkan rat anti-mouse anti-CD $4^{+}$FITC conjugated, dan rat anti-mouse anti $C D 62 L^{+}$ $P E$ conjugated sebanyak $50 \mathrm{ul}$, diinkubasi selama 30 menit pada suhu $4^{\circ} \mathrm{C}$ dalam kondisi gelap. Pelet yang diberi antibodi ditambah 300 $\mu 1$ PBS dipipeting dan dipindah ke dalam tabung flow cytometry. Mesin flow cytometry di setting sesuai pewarnaan dan sampel yang diidentifikasi.

\section{Analisis data hasil flow cytometry dan Analisis Statistik.}

Data hasil analisis flow cytometry dengan menggunakan program CellQuest untuk Machintosh. Data yang dihasilkan berupa jumlah relatif $\mathrm{CD}^{+} \mathrm{CD}_{2} \mathrm{~L}^{+}$(sel $\mathrm{T}$ naif) dan $\mathrm{CD}^{+}{ }^{+} \mathrm{CD}^{2} \mathrm{~L}^{-}$(sel $\mathrm{T}$ memori). Kemudian jumlah relatif sel tersebut dianalisa secara statistik menggunakan uji ANOVA RAL Faktorial dan uji lanjut BNJ dengan menggunakan progam SPSS 16.

\section{Uji Konfirmasi $S$. aureus di dalam darah mencit.}

Uji konfimasi dilakukan pada hari ke-22 setelah setelah injeksi pada hari ke-21. Darah diambil melalui ekor mencit sebanyak $\pm 50 \mu \mathrm{l}$ dan diletakkan didalam eppendorf, kemudian ditambah dengan $450 \mu \mathrm{l} \mathrm{NaCl}$ fis $0.9 \%$. Kemudian darah yang sudah tercampur dengan $\mathrm{NaCl}$-fis, kemudian diinokulasi pada $4.5 \mathrm{ml}$ media NB didalam tabung reaksi. Kemudian dilakukan inkubasi pada shaker dengan suhu $37^{\circ} \mathrm{C}, \quad 120 \mathrm{rpm}$ selama $36 \mathrm{jam}$. Setelah dilakukan inkubasi, maka dilakukan penanaman pada media Mannitol salt agar (MSA). Diambil sebanyak $\pm 2 \mathrm{ml}$ cairan hasil inkubasi pada suhu $37^{\circ} \mathrm{C}$ selama 24 jam. S. aureus merubah warna media dari merah menjadi kuning.

\section{Hasil}

Berdasarkan hasil uji konfirmasi $S$. aureus dengan media MSA, terjadinya perubahan dari warna media tersebut. Hal ini menunjukkan bahwa mencit telah terinfeksi oleh bakteri $S$. aureus. Bakteri tersebut dapat tumbuh pada media dan terjadi fermentasi Mannitol, sehingga warna media berubah dari warna merah menjadi kuning (Beishir, 1991). Warna koloni yang terbentuk pada $S$. aureus dapat bervariasi antara lain putih, kuning dan oranye dimana hanya strain $S$. aureus yang berasal dari sapi dan manusia yang memiliki koloni berwarna kuning keemasan (Purnomo dkk., 2006) (Gambar.1)

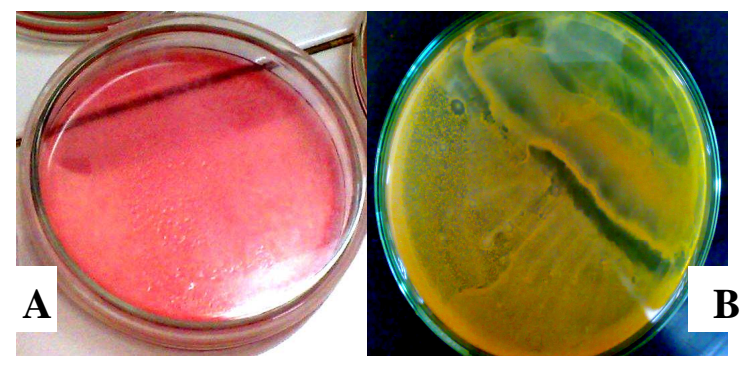

Gambar 1. Uji S. aureus didalam darah menggunakan media MSA ( $\mathbf{A}=$ media MSA tanpa inokulasi $S$. aureus dan $\mathbf{B}=$ media MSA yang telah diinokulasi dengan $S$. aureus, terjadi perubahan dari merah menjadi kuning) 
Jumlah Relatif Sel T Naif $\left(\mathrm{TCD4}^{+} \mathrm{CD62L}^{+}\right)$ dan sel $\mathrm{T}$ memori $\left(\mathrm{TCD4}^{+} \mathrm{CD62L}^{-}\right.$) pada Limpa.

Sel $\mathrm{T}$ naif $\left(\mathrm{CD}^{+} \mathrm{CD}^{2} \mathrm{~L}^{+}\right)$adalah sel limfosit matang yang meninggalkan timus, belum berdiferensiasi dan belum terpapar dengan antigen. Sel T naif yang diaktifkan akan berdiferensiasi menjadi sel efektor dan sel memori yang dapat menetap di organ limfoid atau bermigrasi ke kelenjar nonlimfoid (Baratawidjaja dan Rengganis, 2006). Menurut Abbas dan Lichtman (2005), diferensiasi dari sel $\mathrm{T}$ naif pada organ limfoid perifer diikuti dengan perubahan beberapa molekul adhesi. CD62L atau L-selektin adalah molekul permukaan limfosit yang berperan pada homing limfosit.

Berdasarkan hasil analisis flow cytometry dengan progam CellQuest (Gambar 2), menunjukkan bahwa kelompok non infeksi, jumlah relatif sel $\mathrm{TCD}^{+} \mathrm{CD} 2 \mathrm{~L}^{+}$pada pemberian dosis $25 \mathrm{mg} / \mathrm{kgBB}, 100 \mathrm{mg} / \mathrm{kgBB}$ dan $300 \mathrm{mg} / \mathrm{kgBB}$ sebesar $20.7 \%, 20.5 \%$ dan $13.2 \%$, dibandingkan dengan kontrol normal sebesar $21.6 \%$. Pada kelompok infeksi terjadi penurunan sel $\mathrm{T}$ naif pada kontrol infeksi sebesar $5.7 \%$, kemudian pemberian dosis $25 \mathrm{mg} / \mathrm{kgBB}$ mengakibatkan peningkatan sel $\mathrm{T}$ naif sebesar $7.1 \%$. Pada kelompok infeksi, dosis $100 \mathrm{mg} / \mathrm{kgBB}$ menurunkan jumlah sel $\mathrm{T}$ memori sebesar $2.8 \%$.

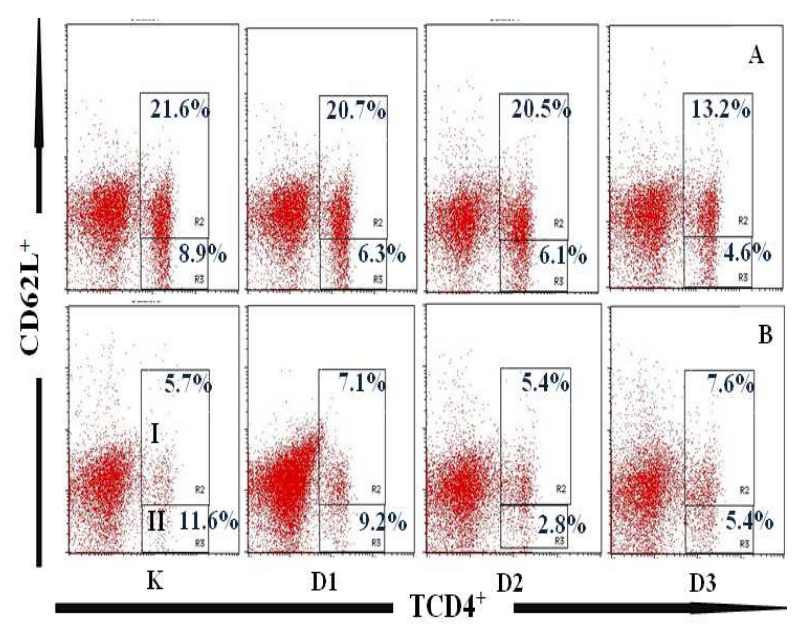

Gambar 2. Persentase rerata jumlah relatif $\mathrm{CD}^{+} \mathrm{CD} 62 \mathrm{~L}^{+}$dan $\mathrm{CD} 4{ }^{+} \mathrm{CD} 62 \mathrm{~L}^{-}$pada setiap perlakuan, dianalisis menggunakan flow cytometry dengan progam CellQuest pada organ limpa (Analisis pada organ limpa menggunakan double staining memakai antibodi anti-CD4 ${ }^{+}$ yang dilabel dengan FITC dan antibodi anti$C D 62 L^{+}$yang dilabel dengan $P E$. I = sel limfosit $\mathrm{T}$ yang mengekspresikan $\mathrm{CD} 4{ }^{+} \mathrm{CD} 62 \mathrm{~L}^{+}$ (sel $\mathrm{T}$ naif), $\mathrm{II}=$ sel limfosit yang mengekspresikan $\mathrm{CD}^{+}{ }^{+} \mathrm{CD} 62 \mathrm{~L}^{-}$(sel T memori), $\mathrm{A}=$ Non Infeksi, $\mathrm{B}=$ Infeksi, $\mathrm{K}=$ Kontrol, D1= Dosis $25 \mathrm{mg} / \mathrm{kgBB}, \mathrm{D} 2=$ Dosis $100 \mathrm{mg} / \mathrm{kgBB}$, $\mathrm{D} 3=$ Dosis $300 \mathrm{mg} / \mathrm{kgBB}$ ).

Berdasarkan hasil analisis statistik uji Anova dan BNJ, pada perlakuan non infeksi jumlah relatif sel $\mathrm{T}$ naif mengalami penurunan secara signifikan $(\mathrm{P}<0.05)$ sebesar $13.2 \%$ pada dosis $300 \mathrm{mg} / \mathrm{kgBB}$. sedangkan jumlah relatif sel $\mathrm{T}$ naif pada dosis $25 \mathrm{mg} / \mathrm{kgBB}$ dan dosis $100 \mathrm{mg} / \mathrm{kgBB}$ tidak berbeda nyata dengan kontrol normal, pada kontrol infeksi jumlah relative sel $\mathrm{T}$ naif mengalami penurunan sebesar $5.7 \%$ dibandingkan dengan kontrol normal sebesar $21.6 \% \quad(\mathrm{P}<0.05) \quad($ Gambar 3$)$. Hal ini menunjukkan bahwa molekul sel $\mathrm{TCD}^{+} \mathrm{CD} 6 \mathrm{~L}^{+}$teraktivasi, sehingga jumlahnya semakin menurun dalam kondisi terinfeksi. Jumlah relatif sel $\mathrm{T}$ memori kelompok non infeksi pada pemberian ketiga dosis tidak berbeda nyata, sedangkan jumlah relatif kontrol positif mengalami peningkatan sebesar $11.6 \%$ dibandingkan kontrol normal $(\mathrm{P}<0.05)$. pemberian dosis $100 \mathrm{mg} / \mathrm{kgBB}$ pada kelompok infeksi menurunkan sel T memori sebesar $2.8 \%$ $(\mathrm{P}<0.05)($ Gambar 4.)

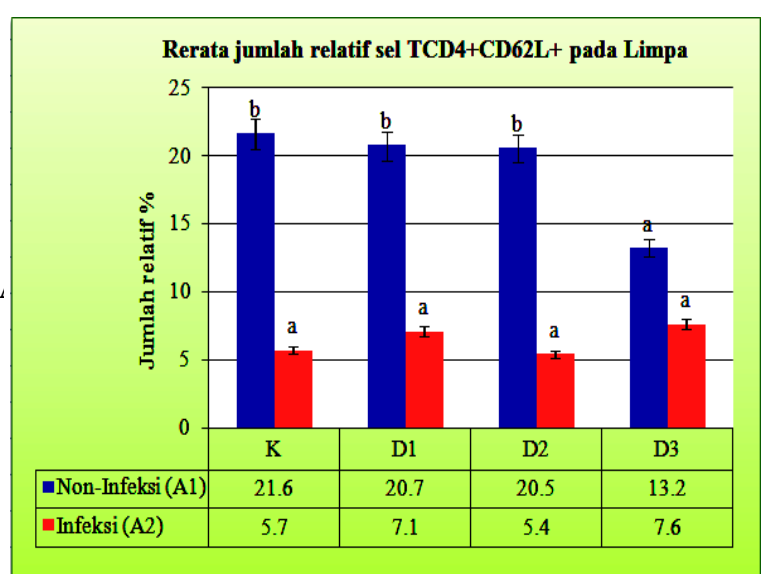

Gambar 3. Rerata jumlah relatif sel $\mathrm{T}$ naif $\left(\mathrm{TCD} 4{ }^{+} \mathrm{CD} 62 \mathrm{~L}^{+}\right)$pada setiap perlakuan hasil analisis statistik uji ANOVA RAL Faktorial dan uji BNJ pada organ limpa ( $\mathrm{K}=\mathrm{Kontrol}$, $\mathrm{D} 1=$ Dosis 25mg/kgBB, D2= Dosis 100 $\mathrm{mg} / \mathrm{kgBB}, \mathrm{D} 3=$ Dosis $300 \mathrm{mg} / \mathrm{kgBB}$ ). 


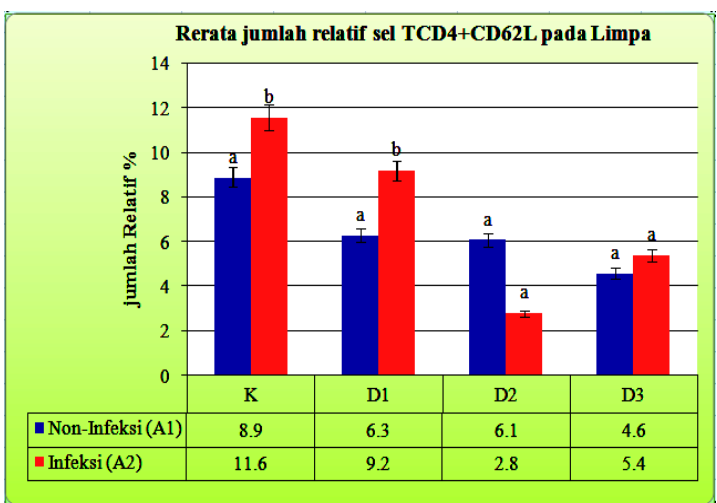

Gambar 4. Rerata jumlah relatif sel T memori pada setiap perlakuan hasil analisis statistik uji ANOVA RAL faktorial dan uji BNJ pada organ limpa ( $\mathrm{K}=$ Kontrol, D1= Dosis $25 \mathrm{mg} / \mathrm{kgBB}$, D2= Dosis $100 \mathrm{mg} / \mathrm{kgBB}$, D3= Dosis 300 $\mathrm{mg} / \mathrm{kgBB}$ ).

Peningkatan dan penurunan sel $\mathrm{T}$ naif dan sel $\mathrm{T}$ memori, kemungkinan disebabkan karena ekstrak air buah mengkudu pada penelitian ini mengandung berbagai macam senyawa aktif. hasil screening fitokimia ekstrak air buah $M$. citrifolia terdapat beberapa senyawa yaitu tannin, alkaloid, fenol, terpenoid, karbohidrat, flavonoid, saponin, glikosida, lipids (Nagalingam et al., 2012). Buah mengkudu (Morinda citrifolia L.) diduga memiliki kandungan skopoletin, antrakuinon, acubin, dan alizarin yang merupakan zat fitokimia dan antibakteria (Djauhariya, 2003). Ekstraksi dan fraksi dari buah mengkudu dapat meningkatkan proliferasi dari splenocyte, yang merupakan sumber dari sel $\mathrm{T}$ dan sel $\mathrm{B}$ (Kralovec et al., 2007). Alkaloid dari mengkudu berperan sebagai imunostimulant (Chan et al., 2006). Peningkatan sel T naif dan memori pada kelompok infeksi disebabkan adanya mitogen dari ekstrak air buah mengkudu. Mitogen dari tumbuhan dapat menginduksi sistem imun yaitu proliferasi dan diferensiasi sel T dan B (Folds et al., 2003).

Sel $\mathrm{T}$ naif merupakan sel $\mathrm{T} \mathrm{CD} 4^{+}$yang mengekspresikan molekul $\mathrm{CD}_{2} \mathrm{~L}^{+}$. Ekspesi CD62L pada sel $\mathrm{T}$ naive dibutuhkan dalam proses sirkulasi didalam darah dan lymph node (Steeber et al., 1996). CD62L disebut juga Lselektin yang tersebar pada bagian sel $\mathrm{B}$, sel $\mathrm{T}$ monosit dan neutrofil (Tibault et al., 2007). CD62L mendukung leukosit untuk melakukan rolling pada endothelium pembuluh darah melalui interaksi dari ligan yang terdapat pada endothelium, termasuk CD34, E-selectin (Rosen, 2004; sassetti, 1998). CD62L ${ }^{+}$yaitu molekul permukaan yang dibutuhkan dalam proses rolling leukosit dan proses aktivasi (Kishimoto et al., 1989). Dalam proses rolling terjadi adhesi antara CD62L dengan ligand yang diekspresikan pada permukaan sel endotel, sehingga menurunkan kecepatan berjalan dari sel limfosit (Warnock et al., 1996).

Berkurangnya ekspresi CD62L pada permukaan sel $\mathrm{T}$ naif $\left(\mathrm{TCD} 4{ }^{+} \mathrm{CD} 62 \mathrm{~L}^{+}\right)$, menunjukkan bahwa CD62L diperlukan oleh sel $\mathrm{T}$ untuk melakukan pelekatan dan rolling pada sel endotel di sepanjang pembuluh darah. CD62L akan terekspresi sangat tinggi pada sel $\mathrm{T}$ naif dan akan menurun pada sel $\mathrm{T}$ yang teraktivasi. CD62L ini memediasi migrasi dari sel T naif menuju ke lymph nodes, pada daerah ini terdapat antigen dan terjadi inisiasi respon imun (Rifai'I, 2011). Ekspresi dari CD62L disebabkan oleh sel $\mathrm{TCD}^{+}$yang berproliferasi dan merespon adanya stimulasi dari antigen (Hengel et al., 2003).

Pada kelompok infeksi sel T memori kontrol infeksi mengalami peningkatan dibandingkan kontrol normal, hal ini menunjukkan bahwa sel T memori aktif ketika terjadi infeksi $S$. aureus. Kemudian terjadi penurunan sel $\mathrm{T}$ memori pada pemberian ketiga dosis terutama dosis 100 $\mathrm{mg} / \mathrm{kgBB}$, hal ini dikarenakan bahan aktif antibakteria dalam buah mengkudu yaitu antrakuinon dan scopoletin yang bersifat lisozim terhadap sel bakteri (Irianto, 2006). Jumlah bakteri yang menurun mempengaruhi terhadap penurunan sel T memori. Berdasarkan penelitian sebelumnya, Sel $\mathrm{T}$ memori tidak memproduksi sitokin atau membunuh sel tetapi dengan cepat mengenali antigen. Sel T memori menunggu terjadinya infeksi kembali (Abbas dan Licthman, 2005). Sel T memori berkaitan dengan dengan sel $\mathrm{T}$ helper 2 (Th2) di dalam sistem imun (Nakagome et al., 2005).

Kesimpulan pada penelitian ini yaitu pada kelompok non infeksi pemberian dosis 25 $\mathrm{mg} / \mathrm{kgBB}$ dan $100 \mathrm{mg} / \mathrm{kgBB}$ tidak berbeda nyata dengan kontrol normal, sedangkan dosis $300 \mathrm{mg} / \mathrm{kgBB}$ terjadi penurunan sel $\mathrm{T}$ naif $(\mathrm{P}<0.05)$. Sel $\mathrm{T}$ naif pada kontol infeksi mengalami penurunan dibandingkan kontrol normal $(\mathrm{P}<0.05)$. Sel $\mathrm{T}$ memori pada kontrol infeksi mengalami peningkatan dibandingkan kontrol normal $(\mathrm{P}<0.05)$ Pada kelompok infeksi dosis $100 \mathrm{mg} / \mathrm{kgBB}$ mampu menurunkan jumlah sel $\mathrm{T}$ memori $(\mathrm{P}<0.05)$. 


\section{Kepustakaan}

Abbas K., and Lichtman A., 2005. Cellular And Molecular Immunology. Fifth Edition. Philadelphia: Saunders Elsivier. 122-123.

Arifiandari dan Condro C., 2007. Pengaruh Pemberian Fraksi Air Buah Mengkudu (Morinda citifolia L.) Terhadap Kadar Glutamat Piruvat Transaminase-Serum Pada Mencit BALB/C Yang Diinduksi Vaksin Hepatitis B. Tesis Pascasarjana. Jurusan Biologi Universitas Gajah Mada. Yogyakarta, Indonesia.

Baratawidjaja, K.G. \& I. Rengganis. 2010. Imunologi Dasar. Jakarta: Balai Penerbit FKUI. 41-411.

Beishir L., 1991. Microbiology in Practice: A Self-Instructional Laboratory Course. $5^{\text {th }}$ ed. HarperCollins Publishers Inc. New York. USA. 446 - 450.

Chan BY., Vaillant F., Perez A., Reynes M., Brillouet J., Brat P., 2006. The noni fruit (Morinda citrifolia L.): a review of agricultural research, nutritional and therapeutic properties. J Food Comp Anal. 19: 645-654.

Djauhariya E., 2003. Mengkudu (Morinda citrifolia L.) Tanaman Obat Potensial, Balai Penelitian Tanaman Rempah dan Obat, J. Perkembangan Teknologi TROL. 15(1):21.

Duncan SH., Flint HJ., and Stewart CS., 1998. Inhibitory activity of gut bacteria against Escherichia coli O157 mediated by dietary plant metabolites. FEMS Microbiology Letters. 164: 258-283.

Folds JD., Schmitz JL., 2003. Clinical and laboratory assessment of immunity. J Allergy Clin Immunol. 111:S70211.

Hengel RL., Thaker V., Pavlick MV., Metcalf AJ., Dennis G., Yang J., Richard A., Lempicki., Sereti I., and Lane H.C., 2003. Cutting Edge: L-Selectin (CD62L) Expression Distinguishes Small Resting Memory $\mathrm{CD}^{+}{ }^{-} \mathrm{T}$ Cells That Preferentially Respond to Recall Antigen. J Immunol. 170:2832.
Hirazumi A., Furusawa E., 1999. An immunomodulatory polysacchariderich substance from the fruit juice of Morinda citrifolia (noni) with antitumour activity. Phytother Res. 13(5):380-7.

Irianto K., 2006. Mikrobiologi, Jilid 1 . Bandung: YramaWidya. 36:77-78.

Jawetz E., Melnick JL., Adelberg EA, Brooks GF., Butel JS., Orston LN., 1996. Mikrobiologi Kedokteran. Edisi 20. Diterjemahkan oleh Nugroho E, Maulany RF. Jakarta: Buku Kedokteran EGC. 211-215.

Kaye MG., Fox MJ., Bartlett JG., Braman SS., and Glassroth J., 1990. The clinical spectrum of Staphylococcus aureus pulmonary infection. Chest. 97: $788-92$.

Kishimoto TK., Jutila MA., Berg EL., and Buther EC., 1989. Neutrophil Mac-1 and MEL-14 adhesion proteins inversely regulated by chemotactic factors. Science. 245: 1238-1241

Kralovec J., Metera K., Kumar J., Watson L., Girouard G., Guan Y., Carr R., Barrow C., Ewart H., 2007. Immunostimulatory principles from Chlorella pyrenoidosa-Part 1: Isolation and biological assessment in vitro. Phytomedicine. 14:57-64.

Lindberg E., Adlerberth I., Hesselmar B., Saalman R., Strannegard IL., Aberg N., Wold AE., 2004. High rate of transfer of Staphylococcus aureus from parental skin to infant gut flora. J. Clin. Microbiol. 42:530-534.

Llewelyn M., Cohen J., 2002. Superantigens: microbial agents that corrupt immunity. Lancet Infect Dis. 2:15662.

Lowy FD., 1998. Staphylococcus aureus infections. N. Engl. J. Med. 339:520-532.

McCormick JK., Yarwood JM., Schlievert PM., 2005. Toxic shock syndrome and bacterial superantigens: an update. Annu Rev Microbiol. 55:77-104.

Murray MT., 2000. Noni juice - the passing of another panacea?. Natural Medicine Online. 3(2): 3.

Nagalingam S., Sasikumar CS., Cherian KM., 2012. Extraction and preliminary 
phytochemical screening of active compounds in Morinda citrifolia fruit. Asian $J$ Pharm Clin Res. 5(2):179-181.

Nakagome K., Dohi M., Okunishi K., To Y., Sato A., Komaqata Y., Nagatani K., Tanaka R., Yamamoto K., 2005. Antigen sensitized $\mathrm{CD} 4{ }^{+} \mathrm{CD} 62 \mathrm{~L}^{\text {low }}$ memory/effector $\mathrm{T}$ helper 2 cells can induce airway hyperresponsiveness in an antigen free setting. Respir Res. 6:46.

Purnomo A., Hartatik., Khusnan., SIO., Salasia., dan Soegiyono., 2006. Isolasi dan Karakterisasi Staphylococcus aureus Asal Susu Kambing Peternakan Ettawa. Media Kedokteran Hewan. 22 (3): 142 147.

Raj V.B.A., Murugamani V., Mounika P., Madhuri B., 2011. Preliminary Phytochemical Investigation of Givotia Moluccana Stem. International Journal of Research in Pharmaceutical and Biomedical Sciences. 2 (3):1307-1313.

Ramesh S., Radhakrishnan M., Anburaj R., Elangomatavan R., Patharajan S., 2012. Physicochemical, phytochemical and antimicrobial studies on Morinda citrifolia L. Fruits at different maturity stages. Int J Pharm Pharm Sci. 4(5): 473476.

Rifa'i, Muhaimin. 2011. Autoimun dan Bioregulator. Malang: UB Press. 28-29.

Rosen SD., 2004. Ligands for L-selectin: homing, inflammation, and beyond. Annu Rev Immunol. 22:129-156.

Sassetti C., Tangemann K., Singer MS., Kershaw DB., and Rosen SD., 1998. Identification of podocalyxin-like protein as a high endothelial venule ligand for L-selectin: parallels to CD34. J Exp Med 187, 1965-1975.

Steeber DA., Green NE., Sato S., Tedder TF., 1996. Lymphocyte migrationin Lselectin-deficientmice: altered subsetmigration and aging of the immune system. J. Immunol. 157:1096.

Stevens DL., 1996. The toxic shock syndromes. Infect Dis Clin North Am. 10:72746.
Tibault S., Tardif MR., Gilbert C., and Tremblay MJ., 2007. Virusassociated host CD62L increases attachment of human immunodeficiency virus type 1 to endothelial cells and enhances trans infection of $\mathrm{CD}^{+} \mathrm{T}$ lymphocytes. Journal of General Virology. 88:2568-2573.

Wang MY., West B., Jensen CJ., Nowicki D., Su C., Palu, AK., Anderson G., 2002. Morinda citrifolia (Noni): a literature review and recent advances in Noni research. Acta Pharmacologica Sinica. 23:11271141.

Warnock RA., Askari EC., Butcher., and Andrian V., 1998. Molecular mechanisms of lymphocyte homing to peripheral lymph nodes. $J$. Exp.Med. 187:205 